\title{
The Mediating Effect of Teachers' Empowerment on Transformational Leadership and School Effectiveness
}

\author{
Indra Devi Maniam ${ }^{1}$, Zaidatol Akmaliah Lope Pihie ${ }^{1}$, Ramli Bin Basri ${ }^{1}$ \\ ${ }^{1}$ Faculty of Educational Studies, University Putra Malaysia \\ *Corresponding Author: Indra Devi Maniam, Faculty of Educational Studies, University Putra \\ Malaysia
}

\begin{abstract}
The purpose of this paper is to develop a conceptual model in exploring the mediating effect of teachers' empowerment on transformational leadership and school effectiveness in Malaysian primary schools. As such, this conceptual paper was developed based on three theories: School Effectiveness Theory (Lezotte and Snyder, 2011), Transformational Leadership Theory (Leithwood and Jantzi, 1995) and Teachers' Empowerment Theory (Short and Rinehart, 1992). Upon extensive review on the past studies, seven dimensions of School Effectiveness, eight dimensions of Transformational Leadership and six dimensions of Teachers' Empowerment were identified to contrast this model.
\end{abstract}

Keywords: School Effectiveness, Transformational Leadership, Teachers' Empowerment

\section{INTRODUCTION}

Making a step in $21^{\text {st }}$ century has witnesses a rapid change in the Malaysian education system. The Malaysian Education Development Plan (2013-2025) has been design to enrich the quality of human capital through a more effective and efficient higher level education system (Muhyiddin Yassin, 2013). Therefore, continuous effort should be taken to ensure the effectiveness of schools as it is believed that an effective school will cater more efficient future human capital (Habib Ismail and Zaimah Ramli, 2012). In order for the school to achieve its effectiveness, the management of the head teacher as a leader should be excellent becausesuccessfulness of a human capital begins at the school level (Najib Razak, 2010; Muhyiddin, 2013; Fullan, 2011; Jamilah Man et al., 2016). As such, in line with the current transformation and reformation in the Malaysian education context, the transformational leadership received the most attention as an ideal leadership in bring about the changes into school (Khalip Musa, 2013). Nevertheless, one must understand that the effectiveness of a school not solely depends on the transformational leader. In materialize the desire of Education Transformation Plan through Malaysian Education Blueprint 2013-2025, teachers had to play major role in school not only in delivering quality teaching and learning but also given opportunity for responsibility, choice, autonomy and authority. As such, teachers' empowerment should be emphasis as much needed aspects by the head teachers in the current $21^{\text {st }}$ century (Rahimah Haji Ahmad \& Simin Ghavifekr, 2014). Moreover, researchers on teachers' empowerment noted that teachers' empowerment as crucial factor that affects the overall effectiveness of the school (Sweetland \& Hoy, 2000: Wall \& Rinehart, 1998). The teachers' empowerment also has become an attractive factor to study in a search for components that promote school effectiveness (Moran, 2015; Mesut Sagnak, 2015).

\section{LITERATURE REVIEW}

\subsection{School Effectiveness}

There is no universally accepted definition for the term of 'effectiveness' due to the differences between the researchers in term of cultural background, their belief and environment (Alammar Laila, 2015). Reviewing literature also indicate no accepted definition on the school effectiveness. However, if there are elementssuch aswhat the student learning and teachers do then it can be considered as acceptable definition. Based on the earlier studies on school effectiveness, many scholars defined school effectiveness based on student academic achievement in socio-economic status, respect to 
gender and ethnic inclination (Dobbie \& Fryer Jr, 2011). Mortimore (1995:7) defines effective school as "One in which the pupils progress further than might be predicted from consideration of their attainment when they enter the school".

Meanwhile, Iyer (2011, p.4) viewed effective school as a school which possess an obseraval positive results among its students, consistenly for a period of time. Whereas according to Brookover and Lezotte (1979) and Teddlie et al. (1985, 1989), the effective schools are schools that improve student academic achievement among student of low Socio-Economic (SES) families.

For the purpose of this paper the school effectiveness is defined based on Lezotte and McKee Snyder (2011). According to these both researchers, school effectiveness is a school with strong leadership, an engaging curriculum, challenging academic standards, effective instruction and positive school climate. In order to measure the school effectiveness, the Seven Correlates of School Effectiveness by Lezotte and Snyder (2011) capturing the following dimensions: high expectation for success, strong instructional leadership, clear and focused mission, opportunity to learn/time on task, frequent monitoring of student progress, safe and orderly environment, and positive school climate will be used. The instrument was developed based on re-envisioning the correlates of earlier studies and it is durable as have been proven over time.

\subsection{Transformational Leadership}

Burns (1978) was the first researcher who introduced the Transformational Leadership. The basic foundation of transformational leadership theory resolves around the importance of transforming others into leaders. However, this theory was improvised over the periods revising all the inadequacies by the earlier researchers. Earlier, Burns theory was based on Maslow's hierarchy of needs whereby he believed that transformational leadership could raise followers from a lower level to a higher level of morality and motivation. Bass (1985) refined and expended Burns' leadership theory by saying that leader encourages the followers to go beyond self-interest for the good of the team or the organization. Bass theory more concentrated on the exchanges between the leader and followers inside the organizations. Then, Bass and Avolio (1998) came with the theory of Full Range of Leadership. Through this Full Range of Leadership, identification and training of potential leader were investigated more systematically. Leithwood and his colleagues have been instrumental in bridging the work of Burns and Bass into fields of educational administration. Leithwood and Jantzi (2000 p.114) used the following seven dimensions to describe transformational leadership: building school vision and establishing schools goals; providing intellectual stimulation; offering individualized support; modelling best practices and important organizational values; demonstrating high performance expectations; creating a productive school culture; and developing structures to foster participation in school decisions. Leithwood also added the following management dimensions to the models of transformational leadership: staffing, instructional support, monitoring school activities and community focus. Then, Leithwood and Jantzi (2006) organized the following dimensions into the following categories: setting direction, developing people, redesigning the organization and managing the instructional program.

As for this paper, the eight dimensions of Leithwood and Jantzi (1995) will be used to measure the transformational leadership: developing shared vision, building goal consensus, holding high performance expectations, models behavior, providing individualized support, providing intellectual stimulation, productive school culture and building collaborative structure. Based on scholars' studies, transformational leadership was proposed an ideal leadership to bring about the changes in schools. In Malaysian context, to be inline with the current National Educational Blueprint (2013-2025), a leader should practices all the dimensions of transformational leadership at its best (Jamilah Man et al., 2016).

\subsection{Teachers' Empowerment}

The literature indicates that the concept of empowerment and teachers' empowerment. Based on the literature, the concept of empowerment first appears in education during the 1980s (Sahar Ahadi, 2012). Then during the 1990s, the concept is used in different areas of studies such as psychology, management business, health, community and education. According to Fotini Kefalidou et al., (2015), empowerment is the transfer of responsibilities and power of decision making with a view to better 
performance at work and to more satisfied employers. Apart from that, empowerment is used for expressing the appreciation and support of the organization leaders regarding their employees (Bogler \& Nir, 2012). Hoy and Miskel (2012) viewed teachers' empowerment as the practice whereby administrators allocate power and encourage or assist teachers to use it in ways that benefits themselves and their professions. Studying the literature review on the theory of empowerment, indicates that the empowerment theory established form the reform for human rights of women and minority groups in 1960s (Anderson, 2007). Earlier, the philosophical foundation of empowerment theory begins with questioning the political and organizational life: justice and fairness, the roots of power, and the role of member of an organization or society (Anderson, 2007 p.29). There were namely two theories underlying the empowerment: (1) Structural empowerment theory; and (2) Psychological empowerment (Anderson, 2007; Abdul Ghani Kanesan et al., 2015). In the education setting, the psychological empowerment Short and Rinehart (1992) makes the first attempt focus on identifying the components of participations' empowerment by the purpose of developing an instrument which is appropriate to participant empowerment in educational institutions. They found six dimensions best describes the psychology empowerment and they are autonomy, professional growth, status, self-efficacy, impact and decision-making (Ronit Bogler, 2010; Archer, 2014).

As for this study, the teachers' empowerment will be measured using the School Participant Empowerment Scale (SPES) by Short and Rinehart (1992). The SPES comprises six dimensions and the instruments are among the most applicable and ideal instrument to measure the teachers' empowerment.

\subsection{Transformational Leadership and School Effectiveness}

Analysing the theories in the literature, the transformational leadership received the most attention as an ideal leadership and current leadership in bring about the changes into school (Wan Hanum Suraya and Jamal Nordin Yunus, 2012; Khalip Musa, 2013). Moreover, current education transformation and school reform brought under the National Blueprint (2013-2025) have called for a leader with transformational abilities (Ryan H Shatzer et al., 2013).Based on previous researcher, transformational leader have three global transformative skills: the headmaster able to identify and sustain a vision of the school which is interpreted as conceptual skills by other researchers; able to stimulate the intellectual of other members of the school and this can only be done by a person who knows the educational process of a school, using a combination of interpersonal and technical skills; and individual consideration for others; the human or interpersonal skills (Aydin Balyer, 2012). The use of these skills was discovered to enhance school effectiveness by transform the teachers to achieve school goals.A study conducted by Jamilah Man, Yahya Don \& Siti Noor Ismail (2016) indicates that's there is positive relationship between the transformational leadership and school leaders with the quality of the teachers. A quality teacher will be able to deliver a quality teaching and learning in the classroom which leads to achieve the school goals. As such, current restructuring in education in Malaysia urged the need of transformational leadership for the school to be effective.

\subsection{Transformational Leadership and Teachers' Empowerment}

Studying the past research indicates that currently in Malaysia transformational leadership has given the priority in managing the schools (Khalip Musa, 2013; Simin Ghavifekr et al., 2014; Wan Marfazila Wan Mahmud et al., 2014).Here transformational leadership is seen at the input stage in the open system.As such, stressing on leadership alone is not sufficient for the school to be effective. Another important factor to be focus is the favourable teachers' empowerment which also an important element in the open system. Past findings on the relationship between the transformational leadership and teachers' empowerment also revealed that transformational leadership has significant and positive effect on teachers' empowerment (Sayyed Mohsen Allameh, et al. 2012). Another study by Khanmohammadi Otaghsara and Mohseni (2010) also demonstrate that there is a relationship among dimensions of transformational leadership and dimensions of psychological empowerment. Hence, transformational leadership affects teachers' empowerment.

\subsection{Teachers' Empowerment and School Effectiveness}

According to Sweetland \& Hoy (2000), there are four assumptions on teachers' empowerment. The assumptions were an effective teacher empowerment should orient to increase teacher 
professionalism, empowerment will have at least two dimensions such as organizational and classroom, empowering teachers has its greatest impact on student achievement when the emphasis is on the core technology of teaching and learning in schools, and an authentic teacher empowerment is needed in order to achieve an effective teacher empowerment (pp. 710-711). Eventually, Wall and Rinehart (1998) indicate that one of the crucial factors that affect school effectiveness is teachers' empowerment. Past finding indicate that teachers' empowerment found to have a stronger relationship with effectiveness (Sweetland \& Hoy, 2000; Short \& Rinehart, 1992; Spreitzer et al., 1997). Hence, teachers' empowerment affects school effectiveness.

\subsection{Mediating role of Teachers' Empowerment in Relationship between Transformational Leadership and School Effectiveness}

Currently, there are growing interests among the researchers and practitioners on teachers' empowerment in shaping the school effectiveness. Earlier finding also indicates that there are significant relationship between teachers' empowerment to student achievements (Marks \& Louis, 1997; Smylie, 1994), school effectiveness (Sweetland and Hoy, 2000) and transformational leadership (Azman Ismail et al., 2011). Moreover, the current transformation under the Education Transformation Plan through Malaysian Education Blueprint 2013-2025, has urged the teachers to play a major role and given opportunity for responsibility, choice, autonomy and authority. The head teacher had to break the one man show and delegate the power to the teachers to enhance students' learning (Sayyed Mohsen Allameh et al., 2012). This is due to the fact that transformational leader at school has no direct effect on students' achievement (Nancy Allen et al., 2015). As such, this study is proposed to examine the role of teachers' empowerment in relationship between transformational leadership and school effectiveness.

\section{CONCEPTUAL RESEARCH FrameWORK}

After reviewing the literature review, this research framework is developed in order to explore the mediating role of teachers' empowerment on transformational leadership and school effectiveness in Malaysian primary schools. The independent variable in this study is the transformational leadership, while teachers' empowerment as the mediating variable and the school effectiveness is the dependent variable. The framework highlights the need for teachers' empowerment in the school management as specific dimensions that will enhance the school effectiveness.

\begin{tabular}{|c|c|c|}
\hline $\begin{array}{l}\begin{array}{l}\text { Transformational } \\
\text { Leadership } \\
\text { (Leithwood and Jant;i, } \\
\text { 1995) }\end{array} \\
\text { 1. Developing shared } \\
\text { vision } \\
\text { 2. Building goal } \\
\text { consensus } \\
\text { 3. Holding high } \\
\text { performance } \\
\text { expectations } \\
\text { 4. Models behariour } \\
\text { 5. Providing } \\
\text { individualized support } \\
\text { 6. Providing intellectual } \\
\text { stimulation } \\
\text { 7. Strengthening school } \\
\text { culture } \\
\text { 8. Building collaborative } \\
\text { structures }\end{array}$ & 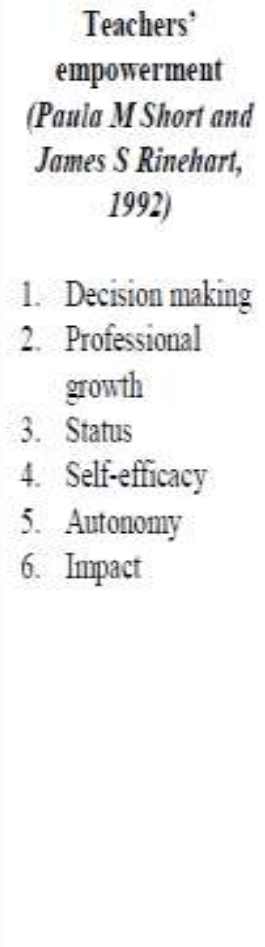 & $\begin{array}{l}\text { School Effectiveness } \\
\text { (Lezotte and Synder, 2011) } \\
\text { 1. High expectation for } \\
\text { success } \\
\text { 2. Strong instructional } \\
\text { leadership } \\
\text { 3. Clear and focused } \\
\text { mission } \\
\text { 4. Opportunity to leam } \\
\text { Time on task } \\
\text { 5. Frequent monitoring } \\
\text { of student progress } \\
\text { 6. Safe and orderly } \\
\text { environment } \\
\text { 7. Positive home-school } \\
\text { relations }\end{array}$ \\
\hline
\end{tabular}

Hypothesized Model1. Linking transformational leadership, teachers' empowerment and school effectiveness 


\section{CONClusion}

School effectiveness has become a major focus in order to deliver quality human capital. As such, transformational leadership is proposed to fulfil the current changes and reformation in education system. Nevertheless, apart from many alternatives undertaken by the Malaysian government, it is still far beyond the Ministry of Education expectations. As such, this study contributes to school effectiveness literature by incorporating the transformational leadership style and teachers' empowerment experienced by Malaysian primary school. These findings will directly benefit the headmasters by informing them of which practices seem to most positively impact teachers and students, thus contributes to the school effectiveness. Besides that, it is hoped that this study can also add more in-depth literature review in academia about the relationship of transformational leadership style, teachers' empowerment and school effectiveness in Malaysia. It can help the new researchers to conduct more comprehensive and complete studies in years to come.

\section{REFERENCES}

[1] Abdul Ghani Kanesan, Tareq Ziad Almadhoun \& Ying-Leh Ling (2015). Organizational Empowerment and Commitment: The Mediating Effect of Psychological Empowerment. Asian Journal of Social Sciences, Arts and Humanities, 3(2): 1-7

[2] Ahadi S. (2012). Mediating Role of Psychological Empowerment In The Relationship Between Structural empowerment and Organizational Culture and Workplace Outcome Among Academics In Malaysian Research Universities. (Doctoral Dissertation).University Putra Malaysia

[3] Allen, N., Grigsby, B., \& Peters, ML. (2015). Does Leadership Matter? Examining the Relationship Among Transformational Leadership, School Climate, and Student Achivement. NCPEA International Journal of Educatioal Leadership Preparation, 10(2)

[4] Archer, M. T. (2014). Teachers' Perception of Empowerment in Christian Schools Accredited by Tennessee Association of Christian Schools. (Electronic Theses and Dissertations). Paper 2457. http://dc.etsu.edu/etd/2457

[5] Aydin Balyer (2012). Transformational Leadership Behaviors of School Principals: A Qualitative Research Based on Teachers' Perception. International Online Journal of Educational Sciences, 4 (3): 581 591

[6] Azman Ismail, Hasan Al-Banna Mohamed, Ahmad Zaidi Sulaiman, Mohd Hamran Mohamad \& Munirah Hanim Yusuf (2011). An Empirical Study of the Relationship between Transformational Leadership, Empowerment and Organizational Commitment. Business and Economics Research Journal, 2(1): 89-107

[7] Bass, B. (1998). Transformational leadership: Industry, military, and educational impact. Mahwah, NJ: Erlbaum Associates.

[8] Bogler, R. \& Nir, A. E. (2012),"The importance of teachers' perceived organizational support to job satisfaction: What's empowerment got to do with it?", Journal of Educational Administration, Vol. 50 Iss: 3 pp. $287-306$

[9] Bolanle, A. O. (2013). Principas' Leadership Skills and School Effectiveness: The Case of South Wastern Nigeria. World Journal of Education, 3(5):26-33

[10] Burns, J. M. (1978). Leadership. NY: Harper \& Row.

[11] Dobbie, W., \& Fryer Jr, R. G. (2011). Getting beneath the veil of effective schools: Evidence from New York City: National Bureau of Economic Research.

[12] Fullan M., (2011). Choosing the Wrong Drivers for Whole System Reform. Seminar series204. Centre for Strategic Education.

[13] Habib Ismail \& Zaimah Ramli (2012). Persidangan Kebangsaan Ekonomi Malaysia ke VII (PERKEM VII). Transformasi Ekonomi dan Sosial Ke Arah Negara Maju. Vol. 2,1471 - 1478

[14] Hoy, W. K. \& Miskel, C. G. (2013). Educational administration: Theory research, and practice, $9^{\text {th }}$ edition. New York: McGraw-Hill

[15] Hoy, W. K., \& Miskel, C. G. (2012). Educational administration: Theory, research, and practice (9th ed.). New York, NY: McGraw-Hill.

[16] Hoy, W.K. \& Miskel, C.G. (2001). Educational administration: Theory, research and practice, 6 th edition. Boston: McGraw-Hill.

[17] Iyer, M.G. (2011). Current views of the characteristics of school effectiveness in the context of national secondary schools from the perception of principals, heads of department and teachers. Retrieved from www.icsei.net/icsei2011/Full\%20Papers/0048.pdf 
[18] Jamilah Man, Yahya Don \& Siti Noor Ismail (2016). Kepimpinan Transformational dan Kualiti Guru Generasi Y. Jurnal Kepimpinan Pendidikan, 3(1): 29-32

[19] Kefalidou, F., Vassilakis, N., Pitsalidis, K. (2015). Soma Aspects of Professional Empowerment to Improve Job Satisfaction of Primary School Teachers. American Journal of Educational Research, 3(12): 1489-1495

[20] Khalip Musa (2013). Study of Transformational Leadership in Malaysia Changing Education Environment : A Case of High Performing Schools. Management Research Journal, 2(1): 69-79

[21] Khanmohammadi Otaghsara, Morteza and Mohseni, Abbas (2010), Studying the impact of leadership styles (transformational, transactional, noninterference) on psychological empowerment, 24th international electricity conference

[22] Laila, Alammar (2015). The Effective School: The Role of the Leaders in School Effectiveness.Educational Research and Reviews, 10(6): 695-721

[23] Leithwood, K. \& Jantzi, D. (2000). The effect of transformational leadership on organizational conditions and student engagement with school. [Electronic version] Journal of Educational Administration 38(2), 112-129.

[24] Leithwood, K. \& Jantzi, D. (2006). Transformational school leadership for large scale reform; effects on students, teachers and their classroom practices. School Effectiveness and School Improvement, 17(2), 201-228.

[25] Leithwood,K. (1995). Cognitive perspectives on leadership. Journal of School Leadership, 5, 115-135.

[26] Lezotte, KM. \& Snyder, KM. (2011). What Effective Schools Do: Re-Envisioning the Correlates, Bloomington, IN : Solution Tree Press.

[27] Lezotte, L. (1989). School improvement based on the effective schools research, International Journal of Educational Research, 13 (7): 815 - 825.

[28] Marks, H. M. \& K. S. Louis (1997). Does teacher empowerment affect the classroom? The implications of teacher empowerment for instructional practice and student academic performance. Educational Evaluation and Policy Analysis, 19 (3), 245-275.

[29] Moran K. A. (2015). Teacher Empowerment: School Administrats Leading Teachers to Lead. (Doctoral Dissertation). Educational Leadership Program in the Younstown State University

[30] Mortimore, P. (1995). Effective School: Current Impact and Future Potential. London: Formara LTD.

[31] Muhyiddin Yassin (2013). Ucapan Penggulungan: Perhimpunan Agung UMNO 2013. Dewan Merdeka, Pusat Dagangan Dunia Putra (PWTC).

[32] Najib Abdul Razak. (2010). "Ucapan Bajet Tahun 2011". Tersedia [online] dalam ttp://www.treasury.gov.my/pdf/bajet/ub11.pdf [dilayari di Langkawi, Malaysia: 10hb April 2014].

[33] Sagnak, M., Kuruoz, M., Polat, B, \& Soylu, A. (2015). Transformational leadership and innovative climate: An examination of the mediating effect of psychological empowerment. Eurasian Journal of Educational Research. 60, 149-162 Doi: 10.14689/ejer.2015.60.9

[34] Sayyed Mohsen Allameh, Marzieh Heydari, Sayyed Mohammad Reza Davoodi, (2012). Studying the relationship between transformational leadership and psychological empowerment of teachers in Abade Township. Social and Behavioral Sciences, 31: $224-230$

[35] Shatzer, R.H., Caldarella, P., Hallam, P.R. \& Brown, B.L. (2013). Comparing the Effect of Instructional and Transformational Leadership on Student Achievement: Implications for Practice. Educational Management Administration \& Leadership, 42(4): 445-459

[36] Short, P. M., \& Rinehart, J. S. (1992). School participant empowerment scale: Assessment of level of empowerment within the school environment. Educational \& Psychological Measurement, 52(4), 951.

[37] Simin Ghavifekr, Mohamad Sani Ibrahim, Sii Ling, Saedah Siraj \& Mohd Ibrahim (2014). Can Transformational Leadership Influence on Teachers' Commitment Towards Organization, Teaching Profession, and Student Learning? A Quantitative Analysis, Asia Pacific Educ. Rev. 15: 177-190

[38] Smylie, Ma. A. (1994). Redesigning teachers' work: connections to the classroom. In L. DarlingHammond (Ed), Review of educational research, Vol. 20 (pp. 129-177). Washington, DC America Educational Research Association.

[39] Spreitzer, G. M., Kizilos, M. A., \& Nason, S. W. (1997). A dimensional analysis of the relationship between psychological empowerment and effectiveness satisfaction, and strain. Journal of Management, 23(5), 679-704

[40] Stolp, S., \& Smith, S. (1995). Transforming school culture: Stories, symbols, values and the leader's role. University of Oregon: ERIC Clearinghouse on Educational Management. 
[41] Suraya, Wan Hanum and Yunus, Jamal Nordin (2012). Principal Leadership Style in High-Academic Performance of Selected Secondary Schools in Kelantan Darul Naim. International Journal of Independent Research and Studies, 1(2): 57-67

[42] Sweetland, S. R. \& Hoy, W. K. (2000). School Characteristic and Educational Outcome: Towards an Organizational Model of Student Achievement in Middle Schools. Educational Administration Quarterly, 36(5): 703-729

[43] Teddlie, Charles and Reynolds, David (2000), The International Handbook of School EffectivenessResearch, London, Falmer Press.

[44] Wall, R., Rinehart, J. S. (1998). School based decision making and the empowerment of secondry school teachers. Journal of School Leadership, 8, 49-64

[45] Wan Marfazila Wan Mahmud, Habibah Ab. Jalil, Masrah Azrifah Azmi Murad (2014). Leadership Patterns among Schools' Administrators in Malaysia. Middle-East Journal of Scientific Reasearch 19 (Innovation Challenges in Multidiciplinary Research \& Practice): 125-132

Citation: Indra, Devi Maniam et al. "The Mediating Effect of Teachers' Empowerment on Transfor mational Leadership and School Effectiveness." International Journal of Humanities Social Sciences and Education (IJHSSE), vol 4, no. 10, 2017, pp. 63-69. doi:http://dx.doi.org/10.20431/2349-0381.0410009.

Copyright: () 2017 Authors. This is an open-access article distributed under the terms of the Creative Commons Attribution License, which permits unrestricted use, distribution, and reproduction in any medium, provided the original author and source are credited. 